УДК 663.25:634.8.07

DOI 10.30679/2219-5335-2021-2-68-308-320

СРАВНИТЕЛЬНАЯ

ХАРАКТЕРИСТИКА

ВИННЫХ СПИРТОВ, ПОЛУЧЕННЫХ ИЗ ТЕХНИЧЕСКОГО И СТОЛОВОГО ВИНОГРАДА

Бахметов Роман Николаевич аспирант

мл. научный сотрудник

лаборатории контроля качества

производства виноградо-

винодельческой продукции

e-mail: baxmetov79@mail.ru

Всероссийский научно-

исследовательский институт

виноградарства и виноделия

имени Я.И. Потапенко - филиал

Федерального государственного

бюджетного научного учреждения

«Федеральный Ростовский аграрный

научный иентр»,

Новочеркасск, Россия

Шелудько Ольга Николаевна

д-р техн. наук, доцент

заведующая НЦ «Виноделие»

e-mail: scheludcko.olga@yandex.ru

Якуба Юрий Федорович

д-р хим. наук, доцент

зав. центром коллективного пользования

«Приборно-аналитический»

e-mail: uriteodor@yandex.ru

Федеральное государственное

бюджетное научное учреждение

«Северо-Кавказский федеральный

научный иентр садоводства,

виноградарства, виноделия»,

Краснодар, Россия

В статье представлены результаты изучения качественных показателей винных спиртов, дистиллятов

и виноматериалов, полученных из разного виноградного сырья, в целях обоснования возможности разработки технологии
UDC 663.25:634.8.07

DOI 10.30679/2219-5335-2021-2-68-308-320

\section{COMPARATIVE \\ CHARACTERISTICS \\ OF WINE ALCOHOLS \\ OBTAINED FROM TECHNICAL AND TABLE GRAPES}

\author{
Bakhmetov Roman Nikolaevich \\ Postgraduate Student \\ Junior Research Associate \\ of Quality Control of Grape \\ and Wine Products \\ Laboratory \\ e-mail: baxmetov79@mail.ru
}

All-Russian Research Institute

named after Ya.I. Potapenko

for Viticulture and Winemaking -

Branch of Federal State

Budget Scientific

Institution «Federal

Rostov Agricultural

Research Center»,

Novocherkassk, Russia

Shelud'ko Olga Nikolaevna

Dr. Tech. Sci., Docent

Head of CS «Wine-making»

e-mail: scheludcko.olga@yandex.ru

Yakuba Yuriy Fiodorovich

Dr. Sci. Chem., Docent

Head of Center of Collective Using

«Instrumental and Analitical»

e-mail: uriteodor@yandex.ru

Federal State Budget

Scientific Institution

"North Caucasian Federal

Scientific Center of Horticulture,

Viticulture, Wine-making»,

Krasnodar, Russia

The article presents the results of studying the quality indicators of wine alcohols, distillates and wine material from various grape raw materials to ground the possibility of developing a technology of high-quality wine spirits, 
качественных винных спиртов, включающей переработку свежего винограда на виноматериалы

без сульфитации, применения ферментных препаратов и осветления виноградного сусла отстаиванием, дистилляцию виноматериалов и ректификацию полученных дистиллятов с применением режимов, позволяющих получить винные спирты крепостью не ниже 94 \% об. Установлено, что у столовых сортов винограда выход виноградного сусла невысокий $-70,8$ дал из 1033 т винограда.

В сухом виноматериале из столовых сортов массовая концентрация летучих кислот превышала максимально установленный предел - 1,60 г/дм ${ }^{3}$ Отмечено, что при дистилляции виноматериалов крепость полученного дистиллята прямо пропорциональна объемной доли этилового спирта исходного сырья и составляла $31,9 \%$ об. (столовый виноград) и 39,5 \% об. (Кристалл). Анализ легколетучих компонентов дистиллятов и винных спиртов показал, что массовые концентрации анализируемых соединений в винных спиртах прямо пропорциональны их содержанию в соответствующих дистиллятах, также прослеживается положительная динамика по снижению нежелательных компонентов в готовом ректификате. Выбранный режим ректификации позволил снизить количество высших спиртов в 1,5 раза для сорта Кристалл и в 4,7 раза для столовых сортов. Содержание сложных эфиров в винных спиртах увеличилось в 2-2,5 раза, преимущественно за счет этилацетата, температура кипения которого близка к температуре кипения этанола. Показано, что для получения качественных винных спиртов целесообразно использовать в качестве сырья некондиционный виноград как технических, так и столовых сортов.

Ключевые слова: ВИННЫЙ СПИРТ, ДИСТИЛЛЯТ, ВИНОГРАДНОЕ СЫРЬЕ, СТОЛОВЫЙ СОРТ, ТЕХНИЧЕСКИЙ СОРТ including the processing of fresh grapes for wine materials without sulfitation and the use of enzyme preparations, and clarification of grape must by sedimentation, distillation of wine materials and rectification of the obtained distillates using the modes that allow to obtain wine alcohols with a strength of at least $94 \%$ vol. It was found hat the yield of grape must of table grape varieties is low - 70.8 dal out of 1033 tons of grapes. In an dry wine material from table varieties, the mass concentration of volatile acids exceeded the maximum permissible limit $1.60 \mathrm{~g} / \mathrm{dm}^{3}$. It is noted that during distillation of wine materials, the strength of distillate obtained is directly proportional to the volume fraction of ethyl alcohol of the original raw material and it was $31.9 \%$ vol. (table grapes) and $39.5 \%$ vol. (Crystal). Analysis of the volatile components of distillates and wine alcohols showed that the mass concentrations of the compounds analyzed in the wine alcohols are directly proportional to their content in the corresponding distillates; there is also a positive trend in reducing undesirable components in the rectificate produced. The selected rectification mode made it possible to reduce the amount of higher alcohols by 1.5 times for the Crystal variety and by 4.7 times for the table varieties. The content of esters in wine alcohols increased in 2-2.5 times mainly due to ethyl acetate, the boiling point of which is close to the boiling point of ethanol. It is shown that to obtain high-quality wine alcohols, it is advisable to use the substandard grapes both table varieties and technical varieties as raw materials.

Key words: WINE ALCOHOL, DISTILLATE, GRAPE RAW MATERIAL, TABLE VARIETY, TECHNICAL VARIETY 
Введение. В России ликерные вина всегда пользовались высоким спросом. В настоящее время согласно требованиям ГОСТ 32715-2014 [1] производство такой продукции возможно путем добавления винных дистиллятов (спиртов), следовательно, для восстановления ассортимента ликерных вин, отвечающих действующим на территории России требованиям, производство спиртующего агента виноградного происхождения является актуальным.

Промышленное производство винограда сконцентрировано на юге России: практически весь объем валового сбора приходится на четыре региона - Краснодарский край (47 \%), Ставропольский край (7 \%), республика Дагестан (20 \%) и республика Крым (17 \%) [2-4]. В России производством винограда занимаются свыше 500 сельскохозяйственных организаций, из них более 100 - крупные виноградарские хозяйства с площадью виноградников около 150 га, со стабильным урожаем столовых и технических сортов винограда [3]. Следовательно, для производства винных спиртов на территории южных регионов России виноградного сырья вполне достаточно.

Кроме того, для эффективности производства винных спиртов можно перерабатывать некондиционный виноград, к которому относятся как столовые сорта винограда, не соответствующие требованиям для реализации (нетоварный вид, не спелый), так и технические сорта винограда с низкими кондициями. Это позволит значительно сократить расходы на издержки, связанные с неполной реализацией полученного урожая, а также затраты на уходные работы за виноградными насаждениями. Совокупность представленных данных позволяет сделать вывод об актуальности приготовления винного спирта из винограда как технических, так и столовых сортов.

Следует отметить, что согласно положениям технического регламента ЕАЭС «О безопасности алкогольной продукции» [5] для приготовления винного ректификата (спирта) в качестве сырья может использоваться сухой ви- 
Плодоводство и виноградарство Юга России № 68(2), 2021 г.

номатериал, полученный из виноградного сусла технических и столовых сортов, не соответствующий действующим стандартам [5], что позволяет не утилизировать виноматериалы, не соответствующие действующей нормативной документации как отходы виноделия, а перерабатывать их с целью получения новых видов продукции из винограда, тем самым повышая рациональность и рентабельность виноградовинодельческой отрасли [6-9].

Как известно, качество готовой продукции зависит от исходного сырья и входящих в его состав компонентов, это касается винного спирта, который в отдельных случаях способен улучшить органолептические свойства ликерного вина. Высокое содержание сивушных масел и ряда других специфических групп соединений способно оказать отрицательное воздействие на качество ликерных вин [10-13]. В свою очередь, качество готовых винных и виноградных спиртов зависит от многих факторов: виноградного сырья, технологических способов переработки, режимов дистилляции [14].

Установлено, что режимы и устройство перегонной установки позволяют улучшить аромат получаемых спиртов, ректификация снижает концентрацию летучих компонентов $[15,16]$. Кроме того, химический состав ректификатов напрямую зависит от того, какое исходное сырье использовалось при дистилляции: здоровый, с дефектом виноматериал или пикет. При изучение химического состава дистиллятов, полученных из окисленного столового вина, выяснили, что приготовленные по классической схеме (шаранской) дистилляты по некоторым химическим показателям отклоняются от значений, необходимых при производстве высококачественных винных дистиллятов (коньячных спиртов) [17]. Существует предположения, что именно режимы ректификации способны повысить качество и безопасность готовых спиртов.

Одним из важнейших контролируемых показателей безопасности готовых винных спиртов является токсичный летучий компонент - метанол, содержание которого стараются максимально снизить в готовой продукции в 
соответствии требованиями стандартов. Так как метанол естественным образом присутствует в винных дистиллятах, авторы исследований [18] в своей работе показали, что образование метанола зависит от значения рН сбраживаемого сусла. Уменьшение активной кислотности сусла до рН 2,5 путем подкисления органическими кислотами, разрешенными в виноделии, способно замедлить процесс образования метанола на 50 \%. Эти данные могут быть использованы при приготовлении виноматериалов для дистилляции.

Таким образом, для получения качественных спиртующих агентов, требуемых в производстве ликерных вин, представляло интерес провести сравнительную оценку винных спиртов, полученных из разного виноградного сырья в целях выявления различий их химического состава в зависимости от направленности сортов винограда (технические или столовые). В связи с чем необходимо провести сравнительный анализ исследуемых образцов винного спирта, полученных из технического и столового винограда, как органолептическим методом (ГОСТ 33817-2016), так и газохроматографическим методом определения летучих компонентов смеси (ГОСТ 33834-2016), позволяющим осуществлять достоверный анализ сложных многокомпонентных смесей благодаря высокой чувствительности и разделительной способности газохроматографических капиллярных колонок [19].

Цель наших исследований - провести сравнительный анализ полученных винных спиртов с объемной долей этилового спирта (94 \%) из технического и столовых сортов винограда, переработанных по единой технологической схеме.

Объекты и методы и исследований. Исследования проводили в условиях экспериментально-производственного цеха виноделия подразделения отдела технологии виноделия Всероссийского научно-исследовательского института виноградарства и виноделия им. Я.И. Потапенко - филиала Федерального государственного научного учреждения «Федеральный Ростовский 
аграрный научный центр» (далее - ВНИИВиВ им Я.И. Потапенко - филиал ФГБНУ «ФРАНЦ») в период 2018-2019 гг. Объектами исследований являлись виноград сорта Кристалл и смесь столовых сортов винограда урожая 2018 года, произрастающие на опытных полях ВНИИВиВ им Я.И. Потапенко - филиала ФГБНУ «ФРАНЦ», а также приготовленные из них столовые сухие белые виноматериалы, дистилляты (спирт-сырец) и винные спирты.

Сухие белые виноматериалы из технического и смеси столовых сортов винограда получали по технологии приготовления столовых виноматериалов из виноградного сусла [20] без использования ферментных препаратов, сульфитации и без отстаивания виноградного сусла для осветления, с внесением чистой культуры винных дрожжей Saccharomyces vini, применением валковой дробилки с гребнеотделителем и пневматического пресса.

Процесс перегонки виноматериалов проводили в два этапа на установке ЛУММАРК (лабораторный универсальный модульный малый ректификационный комплекс), состоящей из дистиллятора и ректификационной колонны. Процесс первичной перегонки и получение спирта-сырца проводили на дистилляторе DV-3, а вторичную перегонку и получение спиртов на малой ректификационной установке РУМ-3 с электрическим нагревом.

Спирт-сырец (далее - дистиллят) получали на дистилляторе DV-3 по следующей технологической схеме: загрузка виноматериалов, прошедших стадию дображивания, в перегонный куб с дистиллятором DV-3; максимальный нагрев с контролем температуры до появления первых капель дистиллята; дистилляция при установленном режиме с контролем температуры и потока дистиллята. При снижении объемной доли этилового спирта поступающего дистиллята ниже 10\% об. процесс перегонки прекращали.

Винные спирты получали на малой ректификационной установке РУМ-3 по следующей технологической схеме: на вторичную перегонку допускали дистилляты с объемной долей этилового спирта 20-45 \% об.; про- 
водили загрузку дистиллята в перегонный куб с колонной РУМ-3; осуществляли максимальный нагрев с контролем температуры с последующей стабилизацией (завершение процесса тепломассообмена); проводили отбор головной фракции 1,0-1,5 \% от объема дистиллята, завершение операции определяли органолептическим способом; отбор основной фракции 15-30\% от объема дистиллята вели до снижения крепости отбираемого спирта и появления постороннего сивушного тона; отбирали хвостовую фракцию 9-15 \% от объема спирта-сырца до снижения объемной доли этилового спирта отбираемого дистиллята менее $10 \%$.

Массовые концентрации основных показателей качества виноматериалов определяли по действующим на территории РФ стандартным методикам ГОСТ и ГОСТ Р. Дегустацию опытных образцов проводили дегустационной комиссией в лаборатории технологии виноделия ВНИИВиВ им Я.И. Потапенко - филиала ФГБНУ «ФРАНЦ». Качественный и количественный состав легколетучих компонентов полученных дистиллятов и винных спиртов определяли с помощью газового хроматографа Кристалл 2000 по ГОСТ 33834-2016.

Обсуждение результатов. Физико-химические показатели виноградного сырья и виноматериалов приведены в таблицах 1 и 2.

\section{Таблица 1 - Исходные показатели виноградного сырья перед сбраживанием}

\begin{tabular}{|c|c|c|c|c|}
\hline Сырье & $\begin{array}{c}\text { Macca, } \\
\text { кг }\end{array}$ & 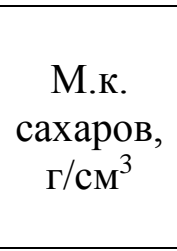 & $\begin{array}{c}\text { М.к. } \\
\text { титруемых } \\
\text { кислот, } \\
\text { г/дм }\end{array}$ & $\begin{array}{c}\text { Кол-во } \\
\text { виноградного } \\
\text { сусла } \\
\text { (жидкой } \\
\text { фракции), дал }\end{array}$ \\
\hline $\begin{array}{l}\text { Виноград } \\
\text { Кристалл }\end{array}$ & 1009 & 23,9 & 3,8 & 59,8 \\
\hline $\begin{array}{c}\text { Столовый } \\
\text { виноград }\end{array}$ & 1033 & 19,6 & 6,2 & 70,8 \\
\hline
\end{tabular}

Из таблицы 1 видно, что по основным нормируемым показателям столовый виноград соответствовал требованиям стандарта ГОСТ 31782-2012 и, 
следовательно, был пригоден для переработки. Отмечен достаточно низкий выход сусла, что обусловлено особенностью сырья. Виноград сорта Кристалл был собран несколько перезревшим, на что указывает низкая массовая концентрация титруемых кислот и недостаточный выход сусла. Также отмечен высокий объем дрожжевой гущи в виноматериалах и увеличение массовой концентрации летучих кислот в сухом белом виноматериале из столовых сортов винограда (см. табл. 2).

Таблица 2 - Характеристики изучаемого сырья для дистилляции, полученного из столового винограда и винограда сорта Кристалл

\begin{tabular}{|c|c|c|c|c|c|}
\hline Сырье & Кол-во, дал & $\begin{array}{l}\text { Об. доля } \\
\text { этилового } \\
\text { спирта, \% }\end{array}$ & $\begin{array}{l}\text { М.к. титр. } \\
\text { кислот, } \\
\text { г/дм } \\
\end{array}$ & $\begin{array}{c}\text { М.к. лет. } \\
\text { кислот, } \\
\text { г/дм }{ }^{3}\end{array}$ & $\begin{array}{l}\text { Кол-во } \\
\text { дрожж. } \\
\text { гущи, } \\
\text { дал }\end{array}$ \\
\hline $\begin{array}{l}\text { Сухой белый } \\
\text { виноматериал } \\
\text { из сорта винограда } \\
\text { Кристалл }\end{array}$ & 58,1 & 14,2 & 4,8 & 0,85 & 1,7 \\
\hline $\begin{array}{l}\text { Сухой белый } \\
\text { виноматериал } \\
\text { из столовых сортов ви- } \\
\text { нограда }\end{array}$ & 68,5 & 11,5 & 7,5 & 1,60 & 2,3 \\
\hline
\end{tabular}

Из таблицы 3 видно, что при дистилляции (первичной перегонке) виноматериалов на спирт-сырец крепость дистиллята была прямо пропорциональна объемной доли этилового спирта исходного перегоняемого сырья и составила 31,9 \% об. (столовый виноград) и 39,5 \% об. (Кристалл). Коэффициент укрепления при перегонке на дистилляторе DV-3 с электрическим нагревом составлял около 3 и обратно пропорционален крепости исходной жидкости.

Известно, что качество дистиллята зависит от его состава, определяемого технологией приготовления и перегонки сухих виноматериалов. В зависимости от температуры кипения все примеси можно разделить на две группы: низкокипящие с температурой кипения ниже, чем у этилового спирта, и высококипящие с температурой кипения выше 78,3 ${ }^{\circ} \mathrm{C}$. 
Таблица 3 - Основные характеристики дистиллятов, полученных из разного виноградного сырья

\begin{tabular}{|c|c|c|c|}
\hline Сырье & $\begin{array}{c}\text { Кол-во, } \\
\text { дал }\end{array}$ & $\begin{array}{l}\text { Об. доля } \\
\text { этилового } \\
\text { спирта, \% }\end{array}$ & $\begin{array}{c}\text { Органолептические } \\
\text { показатели }\end{array}$ \\
\hline $\begin{array}{l}\text { Сухой белый } \\
\text { виноматериал } \\
\text { из сорта винограда } \\
\text { Кристалл }\end{array}$ & 19,8 & 39,5 & $\begin{array}{c}\text { Прозрачный, чистый, с винными } \\
\text { ароматом и вкусом, } \\
\text { без посторонних включений } \\
\text { и осадков }\end{array}$ \\
\hline $\begin{array}{l}\text { Сухой белый } \\
\text { виноматериал } \\
\text { из столовых сортов } \\
\text { винограда }\end{array}$ & 20,4 & 31,9 & $\begin{array}{c}\text { Опалесцирующий, чистый, } \\
\text { с винным ароматом и вкусом, без } \\
\text { посторонних включений и осадков }\end{array}$ \\
\hline
\end{tabular}

Количество низкокипящих примесей незначительно и изменяется в зависимости от состава перегоняемого сухого виноматериала и способа (режима) перегонки. Часть примесей, кипящих при более высокой температуре, чем этиловый спирт, составляют высшие спирты, многие из которых обладают резким сивушным или травянистым запахом и неприятным вкусом [21], в низких концентрациях высшие спирты делают аромат и вкус более сложными.

Из основных летучих компонентов, кипящих при более низкой температуре, чем этиловый спирт, следует выделить альдегиды (ацетальдегид и фурфурол), метанол и эфиры. Количественный анализ перечисленных летучих компонентов в дистилляте позволяет характеризовать исходное сырьё, а в винном спирте наряду с качеством сырья и технологические режимы.

В таблице 4 приведен состав летучих компонентов полученных дистиллятов и винных спиртов. Анализ данных показал, что меньшее количество метанола обнаружено в дистилляте и винном спирте из технического сорта винограда Кристалл, однако и в дистилляте, и винном спирте из столовых сортов винограда массовые концентрации метанола не превышают допустимые нормы. Неприменение сульфитации при приготовление сухих 
Плодоводство и виноградарство Юга России № 68(2), 2021 г.

виноматериалов привело к повышенному содержанию ацетальдегида, 2,3-бутандиола, обусловленному процессами окисления и воздействия различной микрофлоры.

Высокая массовая концентрация сахаров винограда сорта Кристалл обусловила химический состав дистиллята, полученного перегонкой сухого виноматериала из этого сорта, массовые концентрации сложных эфиров и высших спиртов в 1,5 раза выше, чем у дистиллята из столовых сортов винограда.

Таблица 4 - Состав летучих компонентов полученных дистиллятов и винных спиртов (мг/дм б.с.)

\begin{tabular}{|c|c|c|c|c|}
\hline Компонент & $\begin{array}{l}\text { Дистиллят } \\
\text { Кристалл }\end{array}$ & $\begin{array}{c}\text { Винный спирт } \\
\text { Кристалл }\end{array}$ & $\begin{array}{l}\text { Дистиллят } \\
\text { столовый }\end{array}$ & $\begin{array}{c}\text { Винный спирт } \\
\text { столовый }\end{array}$ \\
\hline Крепость, \% об. & 39,5 & 94,6 & 31,9 & 95,1 \\
\hline Ацетальдегид & 9,2 & 17,9 & 3,8 & 10,6 \\
\hline Ацетоин & 0,6 & - & 0,02 & - \\
\hline Метилацетат & 7,8 & 9,0 & 3,3 & 0,7 \\
\hline Этилацетат & 94,0 & 239,2 & 67,6 & 134,0 \\
\hline Изоамилацетат & - & 2,1 & - & 0,4 \\
\hline Этилкапроат & - & - & 0,3 & - \\
\hline Этиллактат & 2,6 & 4,8 & 2,4 & 0,2 \\
\hline Этилкаприлат & 0,2 & - & 0,3 & - \\
\hline Этилкапринат & 0,4 & - & 0,3 & - \\
\hline Этиллаурат & 2,1 & - & 1,7 & 12,2 \\
\hline Метанол & 33,0 & 203,3 & 57,4 & 322,0 \\
\hline 2-Пропанол & 2,1 & 0,2 & 1,5 & 4,3 \\
\hline 1-Пропанол & 34,0 & 61,5 & 34,1 & 46,0 \\
\hline Изобутанол & 81,3 & 47,3 & 47,0 & 10,0 \\
\hline 1-Бутанол & 3,8 & - & 1,8 & - \\
\hline Изопентанол & 393,3 & 5,0 & 183,1 & 2,9 \\
\hline 1-Амилол & 0,3 & - & 0,3 & - \\
\hline Гексанол & 21,2 & 5,0 & 29,7 & - \\
\hline Фурфурол & 1,7 & 0,8 & 1,4 & - \\
\hline 2,3-Бутандиол & 21,5 & 7,9 & 32,3 & - \\
\hline$\beta$-Фенилэтанол & 20,8 & 4,2 & 12,5 & - \\
\hline Сумма сложных эфиров & 107,1 & 255,1 & 75,9 & 147,5 \\
\hline Сумма высших спиртов & 536,0 & 322,3 & 297,5 & 63,2 \\
\hline
\end{tabular}

Сопоставительный анализ легколетучих компонентов дистиллятов и винных спиртов показал, что массовые концентрации изученных соединений в винных спиртах коррелируют с их содержанием в соответствующих 
Плодоводство и виноградарство Юга России № 68(2), 2021 г.

дистиллятах, а также прослеживается положительная динамика по снижению нежелательных компонентов в готовом ректификате. За счет выбранного режима ректификации удалось снизить количество высших спиртов в 1,5 раза для сорта Кристалл и 4,7 раза для столовых сортов, в то время как, содержание сложных эфиров в винных спиртах увеличилось в 2-2,5 раза, преимущественно за счет этилацетата, температура кипения которого близка к температуре кипения этанола.

Bbыводы. Анализ физико-химических показателей и органолептических свойств полученных винных спиртов показал, что состав легколетучих компонентов и органолептические свойства винных спиртов, полученных путем ректификации дистиллятов, в значительной мере зависят от режимов ректификации и состава исходного дистиллята. Для получения качественных винных спиртов целесообразно использовать в качестве сырья как некондиционный виноград технических сортов, так и виноград столовых сортов.

Оптимально подобранные схемы и режимы переработки исходного сырья, перегонки сухих виноматериалов и ректификации дистиллятов позволяют получить винный спирт, с высокой степенью очистки от нежелательных компонентов и сохранением ценных компонентов.

\section{Литература}

1. ГОСТ 32715-2014. Вина ликерные, вина ликерные защищенных географических указаний, вина ликерные защищенных наименований места происхождения. Общие технические условия. М.: Стандартинформ. 6 с.

2. Романенко Е.С., Сосюра Е.А., Нуднова А.Ф., Юхнова А.А. Выращивание винограда для качественного виноделия // Журнал Ставропольского государственного аграрного университета. 2014. № 3(15). С. 185-187.

3. Виноградари идут на рекорд. Но производство вин в стране стагнирует // Журнал «Агринвестор» [электронный ресурс]. 2019 сентябрь. URL: https://www.agroinvestor.ru/markets/article/32348-vinogradari-idut-na-rekord/ (дата обращения 16.01.2021).

4. Раджабов А.К., Мишуров Н.П., Щеголихина Т.А. Состояние и перспективы развития виноградарства, включая питомниководство: науч. аналит. обзор. М.: ФГБНУ Росинформагротех, 2019. 92 с.

5. Технический регламент Евразийского экономического союза ТР ЕАЭС 047/2018 от 5 декабря 2018 «О безопасности алкогольной продукции» 129 с.

6. Ioannis S. Arvanitoyannis, Demetrios Ladas, Athanasios Mavromatis. Wine waste treatment methodology // International Journal of Food Science \& Technology. 2006. Vol. 41. P. 1117-1151. 
7. Zacharof, Myrto-Panagiota. Grape Winery Waste as Feedstock for Bioconversions: Applying the Biorefinery Concept // Waste and Biomass Valor. 2017. Vol 8. P. 1011-1025.

8. Miloš Rajković, Dušanka Popović-Minić, Danijel Milinčić, Milena Zdravković. Circular economy in food industry // Zastita materijala. 2020. Vol 61. P. 229.

9. Matteo Bordiga, Fabiano Travaglia, Monica Locatelli. Valorisation of grape pomace: an approach that is increasingly reaching its maturity - a review // International Journal of Food Science \& Technology. 2019. Vol. 54. P. 933-942.

10. Бабенкова М.А., Христюк В.Т., Струкова В.Е. Изменение содержания биологически активных веществ вин и напитков типа кагор в зависимости от способа внесения и природы спиртующих компонентов // Политематический сетевой электронный научный журнал Кубанского государственного аграрного университета. 2013. № 91. C. 864-875.

11. Бурцев Б.В., Гугучкина Т.И. Влияние спиртующего агента на качество и биологическую ценность ликерных вин // Научные труды КубГТУ. 2016. № 14. С. 481-492.

12. Бурцев Б.В., Гугучкина Т.И. Влияние спиртующего агента на критерии качества ликерных вин Портвейн // Научные труды СКЗНИИСиВ.. Т. 13. Краснодар: СКЗНИИСиВ, 2017. С. 138-142.

13. Дергунов А.В. Зависимость биохимического состава и качества ликерных вин от сортовых особенностей винограда и природы спиртующего агента // Виноделие и виноградарство. 2015. С. 30-34.

14. Хиабахов. Т.С. О нормативно-техническом регулировании качества и безопасности винных дистиллятов // Русский виноград. 2016. Т. 3. С. 189-194.

15. Pau Matias-GuiuJuan José Rodríguez-Bencomo Ignacio Orrio ls José Ricardo Pérez-Correa Francisco López. Floral aroma improvement of Muscat spirits by packed column distillation with variable internal reflux Pau. Food Chemistry. 2016. Vol. 213. P. 40-48.

16. Giuseppe Montevecchi, Francesca Masino, Nicolas Di Pascale, Giuseppe Vasile Simone, Andrea Antonelli. Study of the Repartition of Phthalate Esters During Distillation of Wine for Spirit Production // Food Chem. 2017. Vol. 237. P. 46-52.

17. Posavec, Barbara \& Škvorc, Melanija \& Mihaljević Žulj, Marin \& Tupajić, Pavica. Chemical composition of distillates get from defect wines // Conference: 51 st Croatian and 11 th International Symposium on Agriculture. 2016. P. 195.

18. Glatthar, J. \& Senn, T. \& Pieper, H.J. Investigations on reducing the methanol content in distilled spirits made of Bartlett Pears // Deutsche Lebensmittel-Rundschau. 2001. Vol. 97. P. 209-216.

19. Яшин Я.И., Яшин Е.Я., Яшин А.Я. Газовая хроматография. М.: ТрансЛит, 2009. $528 \mathrm{c}$.

20. Сборник основных правил, технологических инструкций и нормативных материалов по производству винодельческой продукции; под ред. Н.Г. Саришвили. М.: Пищепромиздат, 1998. 244 с.

21. Шелудько О.Н. Инновационные методы оценки и прогнозирования качества винодельческой продукции. Краснодар: ФГБНУ СКЗНИИСиВ, 2017. 291 с.

\section{References}

1. GOST 32715-2014. Vina likernye, vina likernye zashchishchennyh geograficheskih ukazanij, vina likernye zashchishchennyh naimenovanij mesta proiskhozhdeniya. Obshchie tekhnicheskie usloviya. -M.: Standartinform. 6 s.

2. Romanenko E.S., Sosyura E.A., Nudnova A.F., Yuhnova A.A. Vyrashchivanie vinograda dlya kachestvennogo vinodeliya // Zhurnal Stavropol'skogo gosudarstvennogo agrarnogo universiteta. 2014. № 3(15). S. 185-187.

3. Vinogradari idut na rekord. No proizvodstvo vin v strane stagniruet // Zhurnal «Agrinvestor» [elektronnyj resurs]. 2019 sentyabr'. URL: https://www.agroinvestor.ru/markets/article/32348-vinogradari-idut-na-rekord/ (data obrashcheniya 16.01.2021). 
4. Radzhabov A.K., Mishurov N.P., Shchegolihina T.A. Sostoya-nie i perspektivy razvitiya vinogradarstva, vklyuchaya pitomniko-vodstvo: nauch. analit. obzor. M.: FGBNU Rosinformagrotekh, 2019. 92 s.

5. Tekhnicheskij reglament Evrazijskogo ekonomicheskogo soyuza TR EAES 047/2018 ot 5 dekabrya 2018 «O bezopasnosti al-kogol'noj produkcii» $129 \mathrm{c}$.

6. Ioannis S. Arvanitoyannis, Demetrios Ladas, Athanasios Mavromatis. Wine waste treatment methodology // International Jour-nal of Food Science \& Technology. 2006. Vol. 41. P. 1117-1151.

7. Zacharof, Myrto-Panagiota. Grape Winery Waste as Feed-stock for Bioconversions: Applying the Biorefinery Concept // Waste and Biomass Valor. 2017. Vol 8. P. 10111025.

8. Miloš Rajković, Dušanka Popović-Minić, Danijel Milinčić, Milena Zdravković. Circular economy in food industry // Zastita mate-rijala. 2020. Vol 61. P. 229.

9. Matteo Bordiga, Fabiano Travaglia, Monica Locatelli. Valorisation of grape pomace: an approach that is increasingly reaching its maturity - a review // International Journal of Food Science \& Tech-nology. 2019. Vol. 54. P. 933-942.

10. Babenkova M.A., Hristyuk V.T., Strukova V.E. Izmenenie soderzhaniya biologicheski aktivnyh veshchestv vin i napitkov tipa kagor $\mathrm{v}$ zavisimosti ot sposoba vneseniya i prirody spirtuyushchih komponentov // Politematicheskij setevoj elektronnyj nauchnyj zhurnal Kubanskogo gosudarstvennogo agrarnogo universiteta. 2013. № 91. S. 864-875.

11. Burcev B.V., Guguchkina T.I. Vliyanie spirtuyushchego agenta na kachestvo i biologicheskuyu cennost' likernyh vin // Nauchnye trudy KubGTU. 2016. № 14. S. 481-492.

12. Burcev B.V., Guguchkina T.I. Vliyanie spirtuyushchego agenta na kriterii kachestva likernyh vin Portvejn // Nauchnye trudy SKZNIISiV.. T. 13. Krasnodar: SKZNIISiV, 2017. S. 138-142.

13. Dergunov A.V. Zavisimost' biohimicheskogo sostava i kachestva likernyh vin ot sortovyh osobennostej vinograda i prirody spirtuyushchego agenta // Vinodelie i vinogradarstvo. 2015. S. 30-34.

14. Hiabahov. T.S. O normativno-tekhnicheskom regulirovanii kachestva i bezopasnosti vinnyh distillyatov // Russkij vinograd. 2016. T. 3. S. 189-194.

15. Pau Matias-GuiuJuan José Rodríguez-BencomoIgnacio Orrio ls José Ricardo Pérez-CorreaFrancisco López. Floral aroma improvement of Muscat spirits by packed column distillation with variable internal reflux Pau. Food Chemistry. 2016. Vol. 213. P. 40-48.

16. Giuseppe Montevecchi, Francesca Masino, Nicolas Di Pascale, Giuseppe Vasile Simone, Andrea Antonelli. Study of the Repartition of Phthalate Esters During Distillation of Wine for Spirit Production // Food Chem. 2017. Vol. 237. P. 46-52.

17. Posavec, Barbara \& Škvorc, Melanija \& Mihaljević Žulj, Marin \& Tupajić, Pavica. Chemical composition of distillates get from de-fect wines // Conference: 51 st Croatian and 11 th International Sym-posium on Agriculture. 2016. R. 195.

18. Glatthar, J. \& Senn, T. \& Pieper, H.J. Investigations on reducing the methanol content in distilled spirits made of Bartlett Pears // Deutsche Lebensmittel-Rundschau. 2001. Vol. 97. P. 209-216.

19. Yashin Ya.I., Yashin E.Ya., Yashin A.Ya. Gazovaya hromatografiya. M.: TransLit. 2009. $528 \mathrm{~s}$.

20. Sbornik osnovnyh pravil, tekhnologicheskih instrukcij i normativnyh materialov po proizvodstvu vinodel'cheskoj produkcii; pod red. N.G. Sarishvili. M.: Pishchepromizdat, 1998. $244 \mathrm{~s}$.

21. Shelud'ko O.N. Innovacionnye metody ocenki i prognozirovaniya kachestva vinodel'cheskoj produkcii. Krasnodar: FGBNU SKZNIISiV, 2017. $291 \mathrm{s.}$ 